\title{
THE EUROPEAN UNION'S RULE OF LAW PROMOTION IN THE WESTERN BALKANS: BUILDING A RULE OF LAW CONSTITUENCY
}

\author{
Nedim Hogić *
}

\begin{abstract}
This paper deals with the failures in the promotion of the rule of law in the six countries of the Western Balkans that are in different stages of their EU accession process. Drawing on concrete examples from more than two decades of rule of law promotion through the enlargement circles, the paper identifies the different evolutionary stages of this undertaking. It finds that the current dominant paradigm of rule of law conditionality concerning the benchmarking of progress in the areas of Chapters 23 and 24 of the acquis fails to tackle state capture as the main structural obstacle to the rule of law in the Western Balkans. The paper proposes that this situation is to be improved by re-imagining rule of law promotion as an effort focused not merely on standards but on building a rule of law constituency. Four different approaches to rule of law promotion that have been less frequently used so far are offered: legal mobilisation, institutional strengthening, the politicisation of anti-corruption, and economic development. The paper concludes with reflections on the realistic reach of the proposed interventions into efforts to promote the rule of law, arguing that while imperfect they remain necessary in order for the project to succeed.
\end{abstract}

Keywords: European Union, rule of law promotion, Western Balkans, corruption, economic development.

\section{Introduction}

The process of the integration of the WB6 countries (Albania, Kosovo, Montenegro, North Macedonia, Serbia, Bosnia and Herzegovina) into the European Union (EU) has been a lengthy political, legal, and economic transition. Officially, it began in 2003 with the commitment to an enlargement perspective for the WB6 countries made by the EU at the Thessaloniki Summit. ${ }^{1}$ From that point on, the process has experienced

\footnotetext{
"PhD Researcher, Sant'Anna School of Advanced Studies, Pisa, nedim.hogic@santannapisa.it. ORCID iD: 0000-0001-9184-5567. The author would like to thank the editors, two anonymous reviewers, as well as Tom Ginsburg, Giuseppe Martinico, Tena Prelec, Jelena Dzankic and other participants of the seminar 'The EU and the National Legal Systems of the Western Balkans' for their comments that have greatly improved the original draft of this paper. DOI: 10.3935/cyelp.16.2020.377.

${ }^{1}$ European Council, Thessaloniki European Council 19 and 20 June 2003. Presidency conclusions, 11638/03. Brussels, 1 October <www.consilium.europa.eu/media/20847/76279. pdf $>$ accessed 29 May 2020. It should be observed that in 2003 the commitment from both
} 
many highs and lows, but none so dramatic as the 2019 veto by French President Macron of the proposal of the European Commission to open accession negotiations between the EU and North Macedonia and Albania. Heavily criticised, the veto was understood to deprive the countries of their European future. However, much less attention has been given to a part of Macron's statement that referred to these countries as implementing EU legislation without transforming. What this implies is that the process of exporting the principles of democracy, rule of law, and a free-market economy has failed to bring about changes to the legal and political systems of the countries that were to prepare them for EU membership.

Historically, the progress of countries towards full membership in the EU was to 'depend on the performance of the countries themselves in a wide range of reforms of their economies, standards of democracy, human rights, good governance and respect for rule of law'. ${ }^{2}$ These were the so-called 'Copenhagen criteria' against which the progress made by the states should be measured. Transposition of the chapters of the acquis - the EU legislation governing a certain field - into domestic legislation and the enforcement of this legislation was the key domain of progress. But for most analysts writing about the process, the lack of transformation that President Macron referred to was defined as a combination of the EU's unwillingness to promote the principles of rule of law and democracy and the rising authoritarian trends of the national governments in the WB6 countries. ${ }^{3}$ The EU's focus, instead, was the stability of the region. This approach in which the EU favoured stability supporting the governments of the WB6 while turning a blind eye to a standstill in development and even backsliding of democracy and rule of law standards was dubbed 'stabilitocracy'.

The consequences of 'stabilitocracy' in the domain of democratic backsliding were hardly a problem specific for the WB6. The erosion of the rule of law in Poland and Hungary exposed both the weaknesses of

the EU and the Western Balkans countries also included Croatia which joined the EU in 2013.

2 ibid.

${ }^{3}$ Marko Kmezic, EU Rule of Law Promotion: Judiciary Reform in the Western Balkans (Routledge 2016); Jelena Dzankic, Soeren Keil and Marko Kmezic (eds), The Europeanisation of the Western Balkans (Springer 2019); Arolda Elbasani, 'Untangling Europeanization, Compliance and Reform in the Western Balkans: The Missing Link of Domestic Resistance and Accountability' in Vladimir Vuckovic and Vladimir Djordjevic (eds), Balkanizing Europeanization: Fight against Corruption and Regional Relations in the Western Balkans (Peter Lang 2019); Florian Bieber, The Rise of Authoritarianism in the Western Balkans (Palgrave Macmillan 2020).

${ }^{4}$ Florian Bieber, 'Patterns of Competitive Authoritarianism in the Western Balkans' (2018) 34(3) East European Politics 337. 
the judicial system and the loss of constituency in support of the rule of law among citizens. The European Commission's (Commission) Rule of Law Framework, the rulings of the Court of Justice of the European Union (CJEU) in the case of Polish judges (C-619/18), and the Commission's recent plans for further strengthening the rule of law within the Union all recognise the need to act in this regard. A recent Commission communication makes clear that there is a recognised need to build a rule of law constituency. ${ }^{5}$

In this paper, I do not challenge the narrative that explains the emergence or the consequences of 'stabilitocracy'. This concept is both accurate and useful, for it points out the value of political will for the promotion, acceptance, and enforcement of the rule of law. ${ }^{6}$ Instead, I aim to look critically at the promotion of the rule of law as part of the enlargement process, attempting to offer ideas for its reconceptualisation. Scholars who have researched this process have argued that it was contaminated by the EU's pathological power ${ }^{7}$ and lack of true commitment to the rule of law, ${ }^{8}$ which enabled the strengthening of regimes blind to the violation of human rights but favourable to stability. ${ }^{9}$ However, what seems to be missing from the debate is a clear conceptualisation of the ways of promoting the rule of law and a clear alternative to the current model. Relying on ideas that have appeared as alternatives to official EU policies, ${ }^{10}$ this paper aims to bridge this gap and offer an alternative to

${ }^{5}$ Commission, 'Communication: Further strengthening the Rule of Law within the Union. State of play and possible next steps' COM(2019) 163 final.

${ }^{6}$ For the value of the concept of political will in rule of law interventions, see Linn Hammergren, 'Political Will, Constituency Building, and Public Support in Rule of Law Programs' (1998) Center for Democracy and Governance 216. For a more general discussion of the concept for rule of law promotion, see Thomas Carothers (ed), Promoting the Rule of Law Abroad: In Search of Knowledge (Brookings Institution Press 2010).

${ }^{7}$ Martin Mendelski, 'The EU's Pathological Power: The Failure of External Rule of Law Promotion in South Eastern Europe' (2015) 39(3) Southeastern Europe 318.

${ }^{8}$ Dimitry Kochenov, 'Behind the Copenhagen Façade. The Meaning and Structure of the Copenhagen Political Criterion of Democracy and the Rule of Law' (2004) 8(10) European Integration Online Papers 1.

${ }_{9}$ Beata Huszka, 'Human Rights on the Losing End of EU Enlargement: The Case of Serbia' (2018) 56(2) Journal of Common Market Studies 352.

10 'Hamster in the Wheel: Credibility and EU Balkan Policy' (2020) European Stability Initiative <www.esiweb.org/sites/default/files/reports/pdf/ESI\%20-\%20Hamster\%20in\%20 the\%20Wheel\%20-\%2015\%20January\%202020.pdf> accessed 30 May 2020; Jovana Marovic, Marko Kmezic and Tena Prelec, Strengthening the Rule of Law in the Western Balkans: Call for a Revolution against Particularism (2019) BiEPAG <http://biepag.eu/wp-content/ uploads/2019/03/Strengthening-the-Rule of law.pdf> accessed 30 May 2020 35-37; Kurt Bassuener and others, 'The EU Must Shift Out of Neutral in Its Enlargement Strategy: Championing Liberal Values Means Choosing Sides' (2019 Democratization Policy Council) <www.democratizationpolicy.org/pdf/DPC_Policy_Note_Enlargement_Strategy_Shift.pdf> accessed 30 May 2020. 
the status quo that seems content with gradual incremental reforms to the legal systems. It is beyond the scope of this paper to offer a fully developed theory of change that would guarantee success in the promotion of the rule of law. Instead, the paper offers a set of measures that, taken together, could lead to a strengthening of rule of law constituencies in the WB6 countries.

The paper proceeds by explaining the evolution of the rule of law promotion and conditionality in the process of European enlargement from the big-bang enlargement of 2004 to the current situation. It explains the specific challenges to the rule of law promotion that exist in the WB6 countries and offers specific examples of some of the key aspects of both the challenges to rule of law promotion and the promotion strategies that were offered by the EU in the interplay with local actors. I argue that specific policy failures have been unable to prevent state capture. Instead, they have encouraged fake compliance and rule of law reduced to an exercise of discursive practice of European officials. In the third part, the paper proposes some alternative, less used avenues for engagement in rule of law promotion. Specifically, I argue that these avenues can lead to the creation of a rule of law constituency which could be able to counter state capture as the main obstacle to achieving rule of law standards. I conclude that the success of the EU's future role in the promotion of the rule of law depends heavily on its ability to identify and motivate a constituency that would fully participate in such a project. While the paper is prospective, primarily oriented towards the future, it draws on examples of the previous enlargement cycles which is why it revisits both the successes and failures of these undertakings in order to identify successful practices for strengthening the rule of law and pinpointing practices to be (re-)deployed.

\section{The challenges of rule of law promotion in the WB6}

\subsection{Gradual evolution of the EU's rule of law conditionality in the enlargement process}

The latest set of opinions dealing with the accession of the WB6 countries (Albania, Kosovo, Montenegro, North Macedonia, Serbia, Bosnia and Herzegovina) to the European Union (EU) was released in June 2019. ${ }^{11}$ These opinions identify the deficiencies in the rule of law and democratic accountability as among the main reasons why the enlargement by only two countries, namely Serbia and Montenegro, may happen before 2025 and why the accession of the other four is unlikely before

\footnotetext{
${ }_{11}$ The opinions as well as the EU Western Balkans Strategy can be found at <https:// ec.europa.eu/neighbourhood-enlargement/countries/package_en> accessed 29 May 2020.
} 
2030. Coming after 16 years of rule of law promotion projects, such a view raises the question: what state of rule of law should be present before the WB6 states are deemed acceptable for EU accession? And how should the rule of law then be cultivated in these countries?

But to answer this question, we should first address the issue of what conception of rule of law was promoted and how. The answer is much clearer with regards to the how than the what. The how was to be fostered through countless technical projects, financed by both the EU and its Member States, through the secondment of experts, the training of civil service and judicial staff, the implementation of best practices, the adoption of legal standards and diplomatic efforts, and the usage of the rule of law. Depending on the time of their deployment, the practices had three main similar, yet different, focuses. The first was what I call the institutional approach, focused chiefly on institution building, which characterised the big-bang enlargement of 2004. Despite significant warnings of its shortcomings in the progress reports as well as in academic articles, this approach, in a relatively short time (1998-2004), led to the accession of eight countries. The second approach, which I call 'rule of law and the fight against corruption', did not lose sight of institution building, but focused on the specific anti-corruption actions against those charged with political corruption. This model was characteristic of the enlargement of the EU to Bulgaria and Romania in $2007^{12}$ and Croatia in 2013. ${ }^{13}$ Its legacy becomes obvious when we compare the progress reports of any of the countries that joined in the 2004 wave of expansion with the progress reports of any of the WB6 countries as there is a significant increase in attention paid to the specific activities of rule of law and the fight against corruption. ${ }^{14}$ Finally, the current modus operandi focuses on benchmarking specific progress concerning rule of law standards and indicators. ${ }^{15}$ What made this model so different was the realisation that Chapters 23 and 24 of the acquis must become central in the Europeanisation process and that future progress of the country towards EU accession must depend, first and foremost, on this criteri-

\footnotetext{
${ }^{12}$ Kmezic (n 3).

${ }^{13}$ Arolda Elbasani and Senada Selo Sabic, 'Rule of Law, Corruption and Democratic Accountability in the Course of EU Enlargement' (2018) 25(9) Journal of European Public Policy 1317.

${ }^{14}$ For example, the 2002 country report on Slovakia dedicates five pages to the judicial system and fight against corruption. The 2018 opinions on Serbia and Bosnia dedicate ten and thirteen pages respectively.

${ }^{15}$ Kmezic (n 3) 13-15. For an example of specific benchmarks concerning a legal system, see Dragana Lukic, 'EU Accession Negotiations: Analysis of Benchmarks for Montenegro through Comparison with Croatia and Serbia' (2015) Ministry for European Affairs of Montenegro.
} 
on. ${ }^{16}$ Thus, specific progress concerning progress was to be measured through the milestones that the countries pass in the establishment of rule of law standards.

An overview of this evolution demonstrates that the EU did not adhere to a strict definition of the rule of law. As Nikolaidis observes, ${ }^{17}$ this was perhaps a wise choice: by limiting itself to one conception of a term that is so disputed yet so widely used, the EU would unnecessarily limit its manoeuvring space. This evolution shows that the EU was willing to learn from its mistakes and impose stricter conditionality as a result of increased awareness of the fragility of rule of law entrenchment. It also demonstrates a paradox; the more robust and nuanced its approach to rule of law promotion became, the less success it achieved, bringing neither enlargement nor strengthening of rule of law standards.

Figure 1. Evolution of rule of law standards regarding candidate countries

\begin{tabular}{|l|l|l|}
\hline \multicolumn{1}{|c|}{ Candidate countries } & \multicolumn{1}{|c|}{$\begin{array}{c}\text { Main approach to rule of } \\
\text { law promotion }\end{array}$} & $\begin{array}{c}\text { Conception of rule } \\
\text { of law }\end{array}$ \\
\hline $\begin{array}{l}\text { Hungary, Slovakia, } \\
\text { Czechia, Poland, } \\
\text { Lithuania, Latvia, Estonia, } \\
\text { Slovenia, Malta, Cyprus } \\
\text { joined in 2004) }\end{array}$ & Institution building & Thin and formal \\
\hline $\begin{array}{l}\text { Romania, Bulgaria, } \\
\text { Croatia (joined between } \\
\text { 2007 and 2013) }\end{array}$ & $\begin{array}{l}\text { Institution building + 'Rule } \\
\text { of law and fight against } \\
\text { corruption' }\end{array}$ & Thin, but less formal \\
\hline $\begin{array}{l}\text { WB6 (began negotiating } \\
\text { between 2005 and 2014, } \\
\text { expected to join in 2025, at } \\
\text { the earliest) }\end{array}$ & $\begin{array}{l}\text { Institution building + } \\
\text { 'Rule of Law and Fight } \\
\text { Against Corruption' + } \\
\text { Benchmarking }\end{array}$ & Thick and informal \\
\hline
\end{tabular}

This robustness of the current rule of law conditionality that is now crucial for assessing the progress of candidate countries needs to be explained in some detail. Several factors have driven such a development. First, the Co-operation and Verification Mechanism (CVM), a monitoring tool developed for tracking the progress of Romania and Bulgaria in their

\footnotetext{
${ }^{16}$ Wolfgang Nozar, 'The 100\% Union: The Rise of Chapters 23 and 24' (2012) 15(3) Clingendael-Netherlands Institute of International Relations 14.

${ }^{17}$ Kalypso Nicolaidis and Rachel Kleinfeld, 'Rethinking Europe's "Rule of Law" and Enlargement Agenda' (2012) SIGMA Paper No 49 <sigmaweb.org/publicationsdocuments/sigma_sp49_061112_Eng.pdf> accessed 29 May 2020.

${ }^{18}$ In accordance with the EU Western Balkans Strategy (n 11).
} 
fight against corruption, was deemed insufficient for improving the conditions for the establishment of the rule of law. The second factor was the overall negative trends in democratic backsliding which led to what is now an acknowledged rule of law crisis within the EU. ${ }^{19}$ One of the sources of this crisis was found to lie in the fake compliance with rule of law standards that was widespread in the accession process of Romania and Bulgaria. ${ }^{20}$ Considerations over whether their accession could have been managed more efficiently ${ }^{21}$ led the EU to put even greater focus on how the institutions behave and to neglect many of the positive developments that preceded or countered democratic backsliding in the new EU Member States. For example, the rise of populism did not go unchecked; the judiciary, especially in Poland where the political support for the measures undertaken by the regime was also lower, mounted a response that at least limited the extent of state capture and did much to preserve its integrity. The populist surge in Poland and Hungary did not come from the weakness of the legal order but was a direct result of the populist backlash against the liberal order ${ }^{22}$ and the weakness of the mainstream political parties to respond to the financial crisis of $2008 .^{23}$ Far from a lost cause, the fight against corruption in Romania has led to anti-corruption prosecutions becoming a major source of political division between the parties. ${ }^{24}$ And in Bulgaria, while the anti-corruption record remains uneven, the efforts made have exposed the complexity of contextual approaches to anti-corruption. ${ }^{25}$

Finally, the third development that created specific conditions for the application of the evolving EU conditionality was so-called 'enlargement fatigue', a term used to describe a decline in the support of EU

\footnotetext{
19 Tom Ginsburg, 'Demographic Backsliding and the Rule of Law' (2018) 44 Ohio Northern University Law Review 351.

${ }^{20}$ Gergana Noutcheva, 'Fake, Partial and Imposed Compliance: The Limits of the EU's Normative Power in the Western Balkans' (2009) 16 Journal of European Public Policy 1065.

${ }^{21}$ Georgi Gotev, 'Romania and Bulgaria Were Not Ready for Accession, EU Auditors Confess' (EURACTIV, 13 September 2016) <www.euractiv.com/section/enlargement/news/auditors-romania-and-bulgaria-were-not-ready-for-accession>_accessed 29 May 2020.

${ }^{22}$ Eric A Posner, 'Liberal Internationalism and the Populist Backlash' (2017) 49 Arizona State Law Journal 795.

${ }^{23}$ Bojan Bugaric and Alenka Kuhelj, 'Varieties of Populism in Europe: Is the Rule of law in Danger?' (2018) 10(1) Hague Journal on the Rule of Law 21.

${ }^{24}$ Alina Mungiu-Pippidi, 'Explaining Eastern Europe: Romania's Italian-Style Anticorruption Populism' (2018) 29(3) Journal of Democracy 104.

${ }^{25}$ Roxana Bratu, Dimitri A Sotiropoulos and Maya Stoyanova, 'Through the Lens of Social Constructionism: The Development of Innovative Anti-Corruption Policies and Practices in Bulgaria, Greece and Romania, 2000-2015' (2017) 95(1) Slavonic \& East European Review 117. But, see Maria Popova, 'Why Doesn't the Bulgarian Judiciary Prosecute Corruption?' (2012) 59(5) Problems of Post-Communism 35.
} 
citizens and policymakers to the EU's enlargement process. ${ }^{26}$ While not having a direct impact on rule of law standards as such, it had one very practical consequence for the enlargement process. Unlike the previous enlargements (apart from that of Croatia and the one proposed for Turkey) that were to happen over a defined timeframe, the accession of the WB6 might last for an indefinite period. While this gave the EU time to build domestic constituency in support of enlargement, it meant that a sense of urgency with regard to both demand for and supply of the reforms that was present in the previous enlargements was lost.

\subsection{The specific WB6 circumstances for rule of law promotion}

The rule of law was part of the liberal democratic package of values that also included democracy, civil society, and capitalism that was promoted and established in the Central and Eastern European Member States from the 1990s onwards. Coming from communist dictatorship and post-conflict backgrounds, the rule of law and its promotion enjoyed widespread support in both public opinion and in the acts of the EU, and the candidate countries and the WB6 countries were no exception to this rule.

But the consequences of the war conflict of the 1990s meant that no true efforts at democratisation would start before 2000 and that EU commitment towards the European future of the WB6 would only come in 2003. Although the rule of law promotion efforts started even earlier through support for civil society organisations and some immediate post-war state-building (in particular in Kosovo and Bosnia and Herzegovina), the main differentia specifica of the rule of law promotion effort was investment in building local war crimes prosecution capacities. These efforts, coupled with a gradual decrease in the political importance of war crimes prosecutions, resulted in the successful prosecution of thousands of those responsible for war crimes. ${ }^{27}$ Thus, the prosecution of war crimes is no longer a major challenge to the establishment of the rule of law in the WB6, but it drained considerably both domestic and EU resources that would have been useful, as was the case with the candidate countries that joined the EU in 2004, in tackling other rule of law challenges. ${ }^{28}$

\footnotetext{
${ }^{26}$ John O’Brennan, 'On the Slow Train to Nowhere: the European Union, Enlargement Fatigue and the Western Balkans' (2014) 19 European Foreign Affairs Review 221.

27 Aleksandar Ivanović and Lars Soltvedt, 'Investigating and Prosecuting War Crimes in the Western Balkans' (2016) 18(2) Varstvoslovje: Journal of Criminal Justice \& Security 133.

${ }^{28}$ While one could argue that other legacies of war such as the lack of recognition between Serbia and Kosovo or the complex constitutional power-sharing mechanisms in Bosnia were a burden on the rule of law promotion process, I see them as nonviolent conflicts that may fuel national hatred but are non-essential to the rule of law promotion process as such.
} 
But legal certainty, predictability, and the use of law to construct a social order ${ }^{29}$ were more than just empty formal legality and were features of the law in the communist countries. This made the transition to the acquis and other elements of legal modernisation post-1990s easier. The main challenge to the rule of law reforms was the part of communist legacy hostile to the principle of separation of powers, especially the understanding that the judiciary should operate free of any political interference. ${ }^{30}$ In addition to the lack of a proper tradition of separation of powers, the development of the party system restrained the development of the rule of law. Free and fair elections, often with strong international monitoring, were unable to prevent the emerging partitocracy that was fuelled by privatisation and poverty. The privatisation of public companies became a major source of corruption as the companies were in many instances sold at prices below their worth to persons who supported the warring factions of the $1990 \mathrm{~s}^{31}$ or, in cases when they were not privatised, used as sources for the employment of party cadres. ${ }^{32}$ In some instances, the political actors have used the employees of public companies for participation in staged protests, as part of digital trolling machines, ${ }^{33}$ and for the extortion of resources for funding political campaigns. ${ }^{34}$ We should add to all this the dimension of economic development; the WB6 states are the poorest part of Europe (save for Moldova and some regions in Bulgaria) and the state has remained an important employer. Within such a context it is not difficult to see why the political actors operating a vast network of patronage would have a motive to oppose enlargement or to block the successful implementation of rule of law reforms. This would counter the effectiveness of the state capture

${ }^{29}$ Brian Tamanaha, 'A Concise Guide to the Rule of Law' in Gianluigi Palombella and Neil Walker (eds), Relocating the Rule of Law (Hart Publishing 2009) 3.

${ }^{30}$ In this sense, the remnants of old socialist law continue to haunt the former communist states that are now EU members. See Jaakko Husa, 'Developing Legal System, Legal Transplants and Path Dependence' (2018) 6(2) Chinese Journal of Comparative Law 129, 147-149.

${ }^{31}$ Roberto Belloni and Francesco Strazzari, 'Corruption in Post-Conflict Bosnia-Herzegovina and Kosovo: A Deal Among Friends' (2014) 35(5) Third World Quarterly 855; Fernando Casal Bértoa and Dane Taleski, 'Regulating Party Politics in the Western Balkans: The Legal Sources of Party System Development in Macedonia' (2016) 23(3) Democratization 545.

32 'Managing Public Companies: Party Before Expertise' (Centre for Investigative Journalism 2018) <www.cin.ba/en/upravljanje-javnim-preduzecima-stranka-prije-struke/> accessed 29 May 2020.

${ }^{33}$ Daniel Bush, 'Fighting Like a Lion for Serbia: An Analysis of Government-Linked Influence Operations in Serbia' (2020 Stanford Internet Observatory Cyber Policy Center) $<$ https://fsi-live.s3.us-west-1.amazonaws.com/s3fs-public/serbia_march_twitter.pdf > accessed 29 May 2020.

${ }^{34}$ Marovic, Kmezic and Prelec (n 10); Marko Kmezić, 'Rule of Law and Democracy in the Western Balkans: Addressing the Gap Between Policies and Practice' (2020) 1 Southeast European and Black Sea Studies 1. 
project that they were pursuing. ${ }^{35}$ It was state capture that emerged as the most significant factor impeding rule of law reforms and general EU conditionality in the Western Balkans. ${ }^{36}$

On the other hand, one of the major successes the EU has achieved in the WB6 is that there is no credible political force opposing enlargement. ${ }^{37}$ Despite the influence in the region of other countries, such as Russia, China, Turkey, and the United States, there is no other viable long-term political project that could be compared to EU accession in terms of its potential for political and economic development or modernisation. The economy of the WB6 region remains strongly connected to the EU economy ${ }^{38}$ and $\mathrm{EU}$ conditionality remains both a leverage to influence policies and a constraint on decision-making in the countries.

\subsection{The move from the acquis to substance}

The EU enlargement agenda gradually evolved to encompass more and more features. What started out in the wave of enlargement of the 2000s with a focus on the adoption of the acquis has now become a plethora of conditionality commitments stemming from various international legal principles and sources. This is because early EU rule of law promotion focused on the acquis, and the acquis itself provided uneven guidance related to many questions indirectly related to the rule of law. For example, if we take the issue of the management of publicly owned companies, the acquis demanded the independence of electricity-producing companies and their separation from the regulators of the market, as well as full liberalisation of the market in electricity and gas, ${ }^{39}$ but it

\footnotetext{
${ }^{35}$ Soeren Keil, 'The Business of State Capture and the Rise of Authoritarianism in Kosovo, Macedonia, Montenegro and Serbia' (2018) 42(1) Southeastern Europe 59.

${ }^{36}$ Cf Solveig Richter and Natascha Wunsch 'Money, Power, Glory: The Linkages between EU Conditionality and State Capture in the Western Balkans' (2020) 27(1) Journal of European Public Policy 41.

${ }^{37}$ For an evolution of the alignments of political parties in the WB6 with regards to European integration, see Milada A Vachudova, 'Political Parties and Democratic Change in the Western Balkans: When Do External Actors Change Agendas?' (2011) <www.researchgate.net/profile/Milada_Vachudova/publication/2282 12539_Political_Parties_and_Democratic_Change_in_the_Western_Balkans_When_Do_External_Actors_Change_Agendas / links/00463530b67d12d109000000.pdf> accessed 29 May 2020. For an overview of attitudes of citizens of WB6 countries, see 'Balkan Barometer' (Regional Co-operation Council 2019) 37-38 <www.rcc.int/seeds/files/RCC_BalkanBarometer_PublicOpinion_2019.pdf> accessed 29 May 2020.

${ }^{38}$ Milica Uvalić, 'Economic Integration of the Western Balkans into the European Union: The Role of EU Policies' in Dzankic, Keil and Kmezic (n 3).

39 The so-called 'Third energy package' of the EU legislative and policy framework guiding management of companies in the fields of gas and electricity is available at $<$ https:// ec.europa.eu/energy/en/topics/markets-and-consumers/market-legislation/third-energy-package> accessed 29 May 2020.
} 
did not offer a clear model for restructuring public companies or their separation from undue political influence. Such an approach is understandable; the acquis is, after all, a set of EU laws and not a compilation of best practices for privatisation or for the management of public assets. But this ensured that the process of focusing on rule of law reforms contained a few blind spots that were impossible to detect should one choose to focus solely on the acquis. Since the EU itself never clearly defined the rule of law - considering it to be a meta principle on which the EU was founded ${ }^{40}$ - it never scrutinised any of the 'old Member States' in this regard. ${ }^{41}$ In order to resolve this problem, the EU financed many independent observers, mostly coming from civil society organisations that were to identify these shortcomings and report on the situation. But even when taken up by the EU representatives, these recommendations often lacked the normative pull of the acquis rules. The same fate befell the recommendations made by other experts that often argued against evaluations and reports made by the EU experts. ${ }^{42}$ Therefore, the blind spots in the acquis coupled with the EU's lack of an innovative strategy to overcome them left management of public companies as a useful asset for state capture in the WB6.

Instead of working on a specific measure to counter this threat, the EU focused on strengthening conditionality. This meant the application of two things that I have previously referred to: the prominence of Chapters 23 and 24 in the negotiation process, and the introduction of benchmarking. ${ }^{43}$ Defining a set of indicators or milestones to achieve durability and guarantee the functionality of the rule of law seemed a logical move to implement the negative lessons learned through previous enlargements. But for many of the indicators it remains unclear when exactly they are achieved. For example, one of the recommendations from the screening report of the European Commission for the Serbian judiciary reads:

Establish a clear procedure of reaction for the High Judicial Council and the State Council of Prosecutors in situations of political influence on the work of the judiciary and the public prosecutor. ${ }^{44}$

\footnotetext{
${ }_{40}$ Marko Kmezic, 'EU Rule of Law Conditionality: Democracy or "Stabilitocracy” Promotion in the Western Balkans?' in Dzankic, Keil and Kmezic (n 3) 93.

${ }^{41}$ Asya Zhelyazkova and others, 'European Union Conditionality in the Western Balkans: External Incentives and Europeanisation' in Dzankic, Keil and Kmezic (n 3) 16.

${ }^{42}$ Mendelski (n 7) 338.

43 'EU's Benchmarking within Chapters 23 and 24 in Accession Negotiations with Serbia Effects and Challenges' (European Policy Centre 2018) 6 <https://cep.org.rs/en/publications/eus-benchmarking-within-chapters-23-and-24-in-accession-negotiations-with-serbia/> accessed 30 May 2020.

44 'First Draft of the Revised Action Plan for Chapter 23 - Judiciary' (Ministry of Justice of Republic of Serbia 2019) <www.mpravde.gov.rs/files/Action\%20plan\%20Ch\%2023.pdf > accessed 29 May 2020.
} 
The envisaged result of this recommendation is:

In cases of political influence on the work of the judiciary, the High Judicial Council and the State Prosecutorial Council react under clear, predetermined guidelines.

The indicators of achievement of the results have been defined as:

Fundamentally reduced perception of political influence on the work of the judicial bodies among the bearers of judicial functions and among citizens.

Improved transparency of the work of the High Judicial Council and the State Prosecutorial Council and their collaboration with the media.

Undoubtedly, the intentions here are clear: the judicial administration is to react when there are suspicions of undue political influence on the judiciary. Through its reaction, the administration will reinforce the trust of citizens in the independence and impartiality of the work of the judicial bodies. But if the main measurement offered for this is citizens' perception, then we are facing the difficult task of connecting the acts (or lack thereof) of the judicial administration to the perception of citizens. The great anti-corruption campaigns tell us that the relationship between trust and prosecution of political offences is not a oneway street: an increased number of prosecutions does not necessarily lead to greater confidence in the judicial organs. In fact, the experience of the three great judicially led anti-corruption campaigns of the last three decades - those conducted in Italy, Brazil, and Romania - tell us that even impressive top-down efforts to fight political corruption do not necessarily build trust in public institutions. Yet the focus of the capacity-building activities, the so-called 'Twinning projects', in which the best practices of various institutions in the EU would be translated into a different setting, remained focused specifically on increasing the number of prosecutions started. ${ }^{45}$

Thus, capturing change in behaviour or an understanding of societal norms regarding fairness or the perceptions of the judiciary is a task for which the indicators of global governance or country reports used by the EU in assessing the progress of candidate countries remain inadequate. ${ }^{46}$

\footnotetext{
${ }^{45}$ Mendelski (n 7) 334.

${ }^{46}$ See Mila Versteeg and Tom Ginsburg, 'Measuring the Rule of Law: A Comparison of Indicators' (2017) 42(1) Law \& Social Inquiry 100, arguing that while the indicators are not irrelevant what they capture is most likely a perception of impartiality and not necessarily the quality of the public institutions.
} 


\subsection{Specific policy solutions}

Following an institutionally based approach to the quality of rule of law meant that the quality of institutions and their regulatory capacity was one of the key areas of the promotion of the rule of law. But some of the policy solutions applied were either not tested for their significance or produced results that would merely substitute one locus of power for another. For example, a specific mode of court administration replaced the existing model under which judges were appointed by the national parliaments and vetted by the national ministries of justice in almost all new EU Member States, as well as in the WB6 countries. ${ }^{47}$ This model, however, showed itself unable to secure the independence of the judiciary. In the post-2004 EU Member States, the councils were by and large constituted in an independent manner, but found themselves under attack by populist governments. ${ }^{48}$ Thus, as I have argued, they served the purpose of containing increasing state capture, though not its overall suppression. In the WB6, no such frontal assault on the councils happened because the councils gradually became controlled by the political elites (for example, in Bosnia and Herzegovina and North Macedonia), while they preserved their independence but remained largely powerless in the other four WB6 states. The EU did not respond to this by focusing on other aspects of rule of law promotion efforts, but by tightening the conditions for the evaluation of the work of the councils. A comparison of the country reports reveals increased focus on matters related to the judicial administration with many new concerns, such as the quality of testing of judges or their education, which were not even raised in the pre-2004 enlargement. ${ }^{49}$

Much faith was also put in the political parties financing regulation that was, together with conflict-of-interest legislation, to prevent the exercise of undue influence in the public sphere. But the limits of such legislation soon became obvious. Legislation was evaded through the usage of several firms controlled by the same person who would make donations below the legal limit. In cases where the limits were excee-

\footnotetext{
${ }^{47}$ Michal Bobek and David Kosař, 'Global Solutions, Local Damages: A Critical Study in Judicial Councils in Central and Eastern Europe' (2014) 15(7) German Law Journal 1257.

${ }^{48}$ For an overview of the measures that the government of Poland has taken against the independence of the Polish judiciary, see Joint Urgent Opinion of the Venice Commission and the Directorate General of Human Rights and Rule of Law (DGI) of the Council of Europe on Amendments to the Law on the Common Courts, the Law on the Supreme Court, and Some Other Laws (2020) <www.venice.coe.int/webforms/documents/default.aspx?pdffile=CDL-PI(2020)002-e $>$ accessed 29 May 2020.

${ }^{49}$ Commission, Serbia 2019 Report Accompanying the Document Communication from the Commission to the European Parliament, the Council, the European Economic and Social Committee and the Committee of the Regions (2019) COM(2019) 260, 16-17.
} 
ded, the parties were frequently punished, as in Bosnia ${ }^{50}$ and in Serbia, but the practice of courts and administrative bodies to issue minimum mandatory fines undermined the credibility of the process. In addition, the parties had been left with so many other opportunities for the exercise of undue influence that this set of regulations did not really matter much. ${ }^{51}$ Thus, the legislation did not succeed in instilling trust in the political parties and in political representation itself. This had important consequences, as it undermined faith in democracy and the political engagement of citizens. ${ }^{52}$

This increase in imprecise and misguided conditionality did not only - as pointed out earlier - fail to tackle state capture but also led to two important problems. One was the aforementioned fake compliance, and the other was the usage of the rule of law as an element of discourse on European enlargement.

\subsection{Usage of the rule of law as an element of discourse}

By invoking the rule of law, one signals a commitment to a fair ordering of society. As Rajagopal observes, this is 'a desire to escape from politics by imagining the rule of law as technical, legal, and apolitical. ${ }^{53}$ It is beyond the scope of this paper to present all the instances of such invocations made by the European Commission's officials or EU Member States' diplomats aimed at both the general public and the WB6 leaders, but there is substantial evidence of widespread rhetorical practice. ${ }^{54}$

\footnotetext{
50 Jasmin Hasic and Mahir Sijamija, 'Stable and State Subsidized Party Membership in Bosnia and Herzegovina' in Sergiu Gherghina, Alexandra Iancu and Sorina Soare (eds), Party Members and Their Importance in Non-EU Countries (Routledge 2018).

${ }^{51}$ For an explanation of bypassing party regulation, see Gorana Misic, 'Do Regulations Matter? Impact of Political Financing Regulations on Party Corruption in Croatia and Serbia' (Central European University 2018) <https://dsps.ceu.edu/sites/pds.ceu.hu/files/attachment/basicpage/478/misicgoranapp-dissertation2018.pdf>_accessed 29 May 2020.

${ }^{52}$ For example, we observe the decline or stagnation of all WB6 countries in the Freedom House 'Freedom in the World Index' available at <https://freedomhouse.org/> accessed 30 May 2020. Also, for the loss of trust in public institutions in the WB6, see Marta Kolczynska, 'Trust in Democratic Institutions in Western Balkans' in Predrag Cveti anin and Ana Birešev (eds), Social and Cultural Capital in Western Balkan Societies (Institut za Filozofiju i Društvenu Teoriju 2012).

${ }^{53}$ Balakrishnan Rajagopal, 'Invoking the Rule of Law in Post-Conflict Rebuilding: A Critical Examination' (2007) 49 William. \& Mary Law Review 1347.

${ }^{54}$ Part of this is a result of the rule of law revival and defence trend that can be observed in the EU ever since 1993 and its promotion to the former communist countries. An overview of this is offered in Ronald Janse, 'Why Did the Rule of Law Revive?' (2019) 11 Hague Journal of Rule of Law 341. For an exemplary statement of an EU Member State official in this sense, see 'Dialogue is a Powerful Solution' (CorD 29 October 2019) <https://cordmagazine.com/country-in-focus/austria/wolfgang-sobotka-national-council-austria> accessed 30 May 2020: 'Democracy and the Rule of Law Must Be Irreversibly Anchored in the Minds and Hearts of the People of the Western Balkans' (emphasis added). For an overview of the
} 
The rather liberal presentation of the rule of law that would cure all problems of the WB6 countries evolved into something of a rhetorical panacea. Far from being a unique feature of the EU integration process of the WB6, such a move is something that is recorded globally and is used for various purposes: to denote the corruption of a regime, to promote economic reforms, ${ }^{55}$ to advocate for better human rights protection, ${ }^{56}$ and to advance security. ${ }^{57}$

Such invocations of the rule of law are not misplaced. Indeed, the rule of law is important to achieve all the goals mentioned. But reducing the modernisation that EU membership brings to the WB6 countries to the rule of law and the need to attain it is counterproductive. First, such a stance makes all other issues of EU integration less relevant. The EU's acquis has 35 chapters and, while they do not cover all legal norms that a country has, they are certainly crucial for alignment with the EU standards in diverse areas such as environmental protection, agriculture, and public procurement. Second, in situations where such invocations are made without a commitment or an action to change the 'stabilitocracy' paradigm, they might be counterproductive to a rule of law constituency or considered meaningless by the authoritarian regimes. The value of such invocations is to be judged based not on how often they appear but on whether they lead to concrete actions that challenge the state of the rule of law.

\section{Missing rule of law promotion strategies and approaches}

In the previous section, I demonstrated the main paradox of the "stabilitocracy' paradigm; as rule of law conditionality expands, so does state capture in the WB6. As we have seen, various factors - such as policy failures and the discursive practices detached from rule of law promotion efforts - contribute to such a development to a different extent. This leaves state capture processes free to dismantle what is left of the rule of law and democratic constitutionalism in the WB6. Therefore, a rule of

invocations of the rule of law in the EU's strategic documents concerning enlargement, see (n 26) and Council of the EU, 'EU - Western Balkans Justice and Home Affairs ministerial forum - joint press statement' (Press release, 19 November 2019) <www.consilium.europa. $\mathrm{eu} / \mathrm{en} / \mathrm{press} /$ press-releases/2019/11/19/eu-western-balkans-justice-and-home-affairsministerial-forum-joint-press-statement/> accessed 30 May 2020.

55 Joel M Ngugi, 'Policing Neo-Liberal Reforms: Rule of Law as an Enabling and Restrictive Discourse' (2005) 26 University of Pennsylvania Journal of International Economic Law 514.

${ }^{56}$ Clair Apodaca, 'The Rule of Law and Human Rights' (200 4) 87(6) Judicature 292.

${ }^{57}$ Sionaidh Douglas-Scott, 'The Rule of Law in the European Union: Putting the Security into the Area of Freedom, Security and Justice' (2004) 29 European Law Review <https:// papers.ssrn.com/sol3/papers.cfm?abstract_id=2458546> accessed 30 May 2020. 
law-promotion model that aims to engage with state capture is a rule of law model that should aim to replace the current aimless expansion of conditionality.

In this sense, I find Humphreys' analogy between a morality play staged in a theatre and rule of law promotion particularly useful. ${ }^{58}$ Humphreys conceptualises rule of law promotion as a play in which the main actors are the judicial bodies, civil society, and the reform constituency who - despite their occasional tensions - fight on the same side. With the help of the international community, they perform a series of difficult tasks in order to create a better environment for the economy and more opportunities for the poor. The 'bad guys of the story' - authoritarian politicians, corrupt actors, and inefficient governance agents - are disempowered through the concerted effort of actors. In the middle of the play, it becomes evident that the ordeals suffered by the protagonists are important not only for the liberation of the state from capture, but also because the struggle helps their societies in integrating into the global market of capital and goods. The moral of the story is that through hard work and sacrifice, positive changes can be made. While the depiction may sound humorous or even cynical, it is very much in line with reality. It is a crude, but relatively accurate, map of rule of law promotion which - depending on the context - identifies the forces that represent a rule of law constituency that may possess the political will needed for reforms. Consequentially, this constituency represents the demand side of rule of law promotion, while the conditionality and the technical expertise of the EU experts represent the supply side. ${ }^{59}$ It is through the repetition of this play that the shortcomings and unstated assumptions about the functioning of a legal and political system of a society are exposed and that true reform, one that relies on acknowledging the importance of the political will of the actors, becomes possible.

With this in mind, I will try to offer a reconceptualisation of the rule of law promotion approach by highlighting four elements that have proven their worth in the creation of a rule of law constituency, elements that have remained neglected, by exposing their potential and shortcomings. I argue that relying on these alternatives is necessary to change the paradigm of rule of law promotion and lead to change in existing practices.

\footnotetext{
58 Stephen Humphreys, Theatre of the Rule of Law: Transnational Legal Intervention in Theory and Practice (CUP 2010) 24.

${ }^{59}$ Hammergren (n 6) 29-32.
} 


\subsection{Legal mobilisation}

Legal mobilisation is an approach to rule of law promotion that finds its modern expression in the lobbying and advocacy activities of civil society organisations, lobbying groups, political parties, and transnational actors that mobilise the citizenry either through collective action or by enabling them to challenge public authority. ${ }^{60}$ Such actions were often tied to transnational networks of civil society organisations (CSOs) that have transferred some if their knowledge and expertise to local organisations in the WB6. Still, many civil society organisations in the region have legally represented migrants, exposed corruption, provided legal aid, and produced policy proposals on important questions concerning the maintenance of the rule of law. Despite their donor orientation, these organisations are not without knowledge on how to conduct a mobilisation campaign that would reach out to the general population that remains in demand of good governance. ${ }^{61}$

In its operations in the WB6, the EU has reached out to civil society organisations as well as think tanks in an attempt to better understand the 'situation on the ground', but it is hard to pinpoint the effect that this has had on strengthening the rule of law or the integration project itself. Civil society organisations have failed to mobilise society towards rule of law values, acting instead as epistemic communities that disseminate knowledge and expertise. ${ }^{62}$ This has not been without any value; for example, in Kosovo and Serbia this has led to a remaking of whistleblower legislation. ${ }^{63}$ But due to their (usually) foreign sources of funding, the CSOs have - especially in Serbia - often been labelled as foreign agents, ${ }^{64}$ and their reach remains limited to urban centres and the users of social networks. Recent trends in donor support towards democratic accountability demonstrate a turn to independent news organisations

\footnotetext{
${ }^{60}$ Frances K Zemans, 'Legal Mobilization: The Neglected Role of the Law in the Political System' (1983) 77(3) American Political Science Review 690.

${ }_{61}$ 'Corruption in the Western Balkans: Bribery as Experienced by the Population' (United Nations Office on Drugs and Crime 2011) <www.unodc.org/documents/data-and-analysis/statistics/corruption/Western_balkans_corruption_report_2011_web.pdf> accessed 30 May 2020.

${ }^{62}$ For an example of how civil society organisations operate in this sense in Kosovo, see Jacob Phillips, 'The Role of Epistemic Communities: Local Think Tanks, International Practitioners and Security Sector Reform in Kosovo' (2018) 18 Southeast European and Black Sea Studies 281.

${ }^{63}$ Nedim Hogic, 'Whistleblower Protection in Kosovo: What Role for Collective Action?' in Ioannis Armakolas and others (eds), Local and International Determinants of Kosovo's Statehood (The Kosovo Foundation for Open Society 2019) 37.

${ }^{64}$ Sladjana Danković and Paula Pickering, 'Public Scepticism of Internationally Supported Civil Society Organisations: Norms, Citizen Priorities, and Local Groups in Post-Socialist Serbia' (2017) 33(2) East European Politics 210.
} 
and outlets, which have blossomed in the WB6 region in the past decade. While their reporting has - due to its exposure of corruption and informal networks - caused many a headache among the ruling elites, an assessment of their impact remains inconclusive. The donor logic seems to operate under the presumption that voter information is a key factor in reaching a decision on who to support in the elections. But a growing body of literature from the field of political science demonstrates that the involvement of party leaders in fraud, bribery, voter intimidation, and violence does not necessarily reduce their electoral support. ${ }^{65}$ In the situation where the exposure of citizens to information on corruption leads to a reduction of this support, it is the novelty of such data or the innovative way in which they are presented that are key factors for success. ${ }^{66}$ Therefore, the donor community should focus on supporting those civil society organisations that are willing and able to engage in legal mobilisation.

CSOs should focus on the documentation and evidence of the violations of law that arise out of activities of the political machines operated by the parties. This would involve electoral fraud, employer rights violations, negative media campaigns, and discrimination exercised in order to enforce state capture. Such changes of focus would require a change to the existing policy of the EU's support of CSOs. The current framework governing support to the civil society sector as a whole remains vague and is focused on their sustainability and involvement in decision-making processes and not on their work. ${ }^{67}$ While individual donors, such as Member States, might cater for different needs, it is a change of the overreaching strategy that is necessary. This is not impossible, nor does the region's limited tradition of social engagement - often quoted as limiting options for the more successful engagement of individuals ${ }^{68}-$ present an insurmountable task. The success stories, such as the legal mobilisations that have led to an increase in the rights and freedom of assembly of the lesbian, gay, bisexual, and transgender (LGBT) populati-

\footnotetext{
${ }^{65}$ Alberto Chong and others, 'Does Corruption Information Inspire the Fight or Quash the Hope? A Field Experiment in Mexico on Voter Turnout, Choice and Participation' (2015) 77(1) Journal of Politics 55.

${ }^{66}$ Claudio Ferraz and Federico Finan, 'Exposing Corrupt Politicians: The Effect of Brazil's Publicly Released Audits on Electoral Outcomes' (2008) 123(2) Quarterly Journal of Economics 703.

${ }^{67}$ DG Enlargement, 'Guidelines for EU Support to Civil Society in Enlargement Countries, 2014-2020' (June 2015) <http://europa.ba/wp-content/uploads/2016/12/Guidelines-for-EU-support-to-civil-society-in-enlargement-countries-2014-2020.pdf> accessed 30 May 2020.

${ }^{68}$ For example, see a rather gloomy perspective of cultural backwardness as a cause of low social engagement in Goran Zeravcic, 'Mapping Study of Civil Society Organizations in BiH' (EPRD 2016) 49 <http://europa.ba/wp-content/uploads/2016/11/Mapping-studyof-CSOs-in-BiH.pdf> accessed 29 May 2020.
} 
on, provide evidence that such mobilisation is possible. ${ }^{69}$ This mobilisation would send a message that there is a strong network of lawyers and experts willing to challenge the steps taken against those victimised by the ruling regimes, and would require no legislative action since all measures undertaken against individuals are illegal under the laws of the WB6 countries. In addition, many watchdog CSOs that conduct extensive monitoring activities could easily extend their operations to this field and contribute their expertise to legal mobilisation.

\subsection{Institutional strengthening with a specific focus}

Institutions, their work, and quality are essential to the rule of law. Therefore, much of the effort in rule of law building and the fight against corruption focuses on institution building. In the WB6 region, this process commenced from the early 2000s, leading to the creation of legal institutions that closely follow those in the new EU Member States. For example, all countries in the region have established judicial and prosecutorial councils as institutions separated from the other branches of government, or numerous independent oversight bodies. But unlike the institutions in the new EU Member States that were staffed in an independent manner, many of the institutions created in the WB6 countries - while following the same institutional blueprint - were captured. Thus, the process of their creation ran parallel to the simultaneous process of pressures on these institutions from the political elites. ${ }^{70}$ Thus, in North Macedonia, an illegal system of wiretapping organised by the government of Nikola Gruevski was weaponised against his political opponents. ${ }^{71} \mathrm{~A}$ dramatic decline in the prosecution of grand corruption was recorded in Bosnia in the 2011-2019 period, ${ }^{72}$ and an all-out attack on independent institutions has been one of the main features of the government of Aleksandar Vucic in Serbia. ${ }^{73}$ Instances of dramatic whistleblowing exposures of corrupt dealings in Kosovo have failed to mobilise any adequate reaction from institutions.

It is of essential importance that the institutions key to rule of law promotion regain credibility. But as I described in the previous section,

\footnotetext{
${ }^{69}$ Safia Swimelar, 'LGBT Rights in Bosnia: The Challenge of Nationalism in the Context of Europeanization' (2019) Nationalities Papers 1.

70 Bieber (n 3) 82.

${ }^{71}$ Sabrina P Ramet, 'Macedonia's Post-Yugoslav Reality: Corruption, Wiretapping, and Stolen Elections' in Sabrina P Ramet, Christine M Hassenstab, Ola Listhaug (eds), Building Democracy in the Yugoslav Successor States, Accomplishments, Setbacks, Challenges since 1990 (CUP 2017) 287.

72 Keil (n 35) 66.

${ }^{73}$ Branko Radeljić 'Tolerating Semi-authoritarianism? Contextualising the EU's Relationship with Serbia and Kosovo' in Džankić, Keil and Kmezić (n 3) 157.
} 
setting unrealistic goals in terms of trustworthiness is hardly a winning formula. A more sensible approach would be a shift towards activities that focus on reputation-seeking and reputation-building activities for their leaders. ${ }^{74}$ For example, a comparative overview of the work of anti-corruption agencies in the region reveals that leadership based on reputational prestige in the institutions is an element that serves to protect them from undue political influence. ${ }^{75}$ Strengthening external support for these situations may lead to more reputation-seeking activities undertaken by the leaders of these institutions. Such was the case with Romania; strong external support favoured the activities of the leading anti-corruption public prosecutor Laura Kövesi. Additionally, support for lower ranking officials may be granted through more insistence on the enforcement of whistleblower legislation that would allow them to report on misuses of public power.

In this sense, the model of the so-called 'Priebe report' can serve as a tool for focusing institutional tasks that would prevent state capture. The Priebe reports, named after a former EU Commission Director, have mapped the scope of state capture in North Macedonia ${ }^{76}$ that served to prioritise the actions needed for the state to fight capture. ${ }^{77}$ These reports precisely described all the actions needed to return control of the captured institutions, in this case the national security agency of North Macedonia, to democratically elected and appointed institutions and restore integrity to the electoral process. ${ }^{78}$ Tailor-made reports for each

\footnotetext{
${ }^{74}$ For the function of reputation-seeking activities in administrative agencies, see Daniel $\mathrm{P}$ Carpenter, The Forging of Bureaucratic Autonomy: Reputations, Networks, and Policy Innovation in Executive Agencies, 1862-1928 (Princeton University Press 2001) and for their value in more efficient judicial making, see Nuno Garoupa and Tom Ginsburg, Judicial Reputation: A Comparative Theory (University of Chicago Press 2015).

${ }^{75}$ Slobodan Tomic, Explaining Enforcement Patterns of Anticorruption Agencies: Comparative Analysis of Five Serbian, Croatian and Macedonian Anticorruption Agencies (London School of Economics 2016) <http://etheses.lse.ac.uk/3370/1/Tomic_Explaining_Enforcement_Patterns.pdf> accessed 29 May 2020.

76 'The Former Yugoslav Republic of Macedonia: Recommendations of the Senior Experts' Group on Systemic Rule of Law Issues Relating to the Communications Interception Revealed in Spring 2015'<https://ec.europa.eu/neighbourhood-enlargement/sites/near/ files/news_corner/news/news-files/20150619_recommendations_of_the_senior_experts_ group.pdf> accessed 29 May 2020.

${ }^{77}$ However, the Priebe Report issued for Bosnia and Herzegovina in 2019 was much less clear in the sense that it focused on variables such as trust and culture instead of concrete steps that need to be taken to address the crisis within the $\mathrm{BiH}$ judiciary. See Harmut Rank and Mahir Muharemovic, Bosnien und Herzegowina: 'Priebe'-Bericht erschienen (Konrad Adenauer Stiftung 2020) <https://www.kas.de/documents/252038/7938566/Bosnien+und+Herzegowina\%2C+Priebe-Bericht+erschienen.pdf/97343b8c-671c-b8bc-241551 acf758487d?version $=1.1 \& \mathrm{t}=1578325474590>$ accessed 25 November 2020.

${ }^{78}$ Commission, Urgent Reform Priorities for The Former Yugoslav Republic of Macedonia (2015) <https://ec.europa.eu/neighbourhood-enlargement/sites/near/files/news_corner/ news/news-files/20150619_urgent_reform_priorities.pdf > accessed 30 May 2020.
} 
of these countries would serve as a complementary tool to the progress reports and Commission opinions, which are often technical, imprecise, and unclear, ${ }^{79}$ with a tendency to underestimate the specific rule of law challenges. ${ }^{80}$

\subsection{Politicisation of anti-corruption}

The systemic nature of corruption in the WB6 countries is also a style of governance of the political projects present therein. Evidence from the region, as well as from the EU, suggests that rule of law backsliding strongly correlates to the existence of an illiberal project run by a political party in power, ie, in Serbia by the SNS, in Bosnia the SNSD, and in North Macedonia the VMRO. ${ }^{81}$ Operating under the previously described model of 'stabilitocracy', the EU never engaged in a project to undermine the authority of the specific political leaders, considering this to be an infringement of sovereignty. ${ }^{82}$ On the contrary, when the former PM of North Macedonia, Nikola Gruevski, fled the country facing charges of misuse of public funds, he found asylum in Hungary, an EU Member State. ${ }^{83}$ While the mass prosecution of those organising illegal activities is a desirable course of action, we must observe that the chances of such an outcome remain slim. Major anti-corruption campaigns such as those in Romania, Italy, or Brazil have emerged as reputation-seeking activities of the prosecutors and judges. In the absence of preconditions for such activities from the judges and prosecutors we are to look to the legal and political alternatives to these events that may lead to a corruption-reducing outcome.

\footnotetext{
${ }^{79}$ Marovic, Kmezic and Prelec (n 10) 35-37.

${ }^{80}$ It seems that a lack of a uniform methodology focuses on issues seen to be different with respect to which 'team of writers' covers which areas. For example, the country report for Serbia in 2018 recognises corruption in education as a problem, yet the report for Bosnia and Herzegovina for the same year does not, despite the presence of a significant number of so-called 'degree mills' in both countries. See Commission, Communication Staff Working Document, Serbia 2019 Report COM (2019) 260 final; Commission, Commission Opinion on Bosnia and Herzegovina's application for membership of the European Union (Communication) COM (2019) 261 final.

${ }^{81}$ Laurent Pech and Kim Lane Scheppele, 'Illiberalism within: Rule of Law Backsliding in the EU' (2017) 19 Cambridge Yearbook of European Legal Studies 3.

82 Srdja Pavlovic, 'West Is Best: How "Stabilitocracy" Undermines Democracy Building in the Balkans' (LSE European Politics and Policy Blog, 5 May 2017) <https://blogs.lse.ac.uk/ europpblog/2017/05/05/west-is-best-how-stabilitocracy-undermines-democracy-building-in-the-balkans/> accessed 30 May 2020.

${ }^{83}$ Sinisa Jakov Marusic, 'Macedonia's Gruevski Gets Hungary Asylum, Alleges Murder Plot' (Balkan Insight, 20 November 2018) <https://balkaninsight.com/2018/11/20/macedonia-s-gruevski-accuses-of-assassination-plot-11-20-2018/> accessed 30 May 2020.
} 
We find an example of such process in the political events of Slovakia of the 1990s. An often-overlooked episode of its fight against state capture from the late 1990s sheds light on creative uses of both conditionality and support for CSOs as elements of an effective strategy in this sense. Unlike other Eastern European countries that were EU candidates during the late 1990s, Slovakia was considered 'a black hole in the heart of Euro$\mathrm{pe}^{\mathrm{84}}$ because of its backlog in EU integration caused by the authoritarian style of government promoted by the then-political leader Vladimir Meciar. Between 1993 and 1998, Slovakia's public administration grew by 73\% with almost all the new appointees coming from Meciar's HDZS (Movement for Democratic Slovakia) party. ${ }^{85}$ The populist and nationalist policies of Meciar led to confrontation-style politics with the unfair targeting of both neighbouring countries and domestic political opponents.

While the credit for his removal rests with the Slovak people, it was the support received through foreign assistance that strengthened popular mobilisation against a regime that exhibited many features of state capture. This support primarily meant technical assistance to CSOs that were skilled in mobilising voter turnout for the 1998 elections and that managed to influence the media with pro-EU sentiment. ${ }^{86}$

Later analysis also demonstrated that the problem of corruption in Slovakia was overstated ${ }^{87}$ and that Slovakia as a whole was often unfairly equated with Meciar. ${ }^{88}$ Be that as it may, after Meciar lost the 1999 presidential elections, a coalition of civil society organisations assisted the government with the promotion of business-friendly legislation, tax reform, strengthening of the rule of law, and democratic consolidation. However, Slovakia prosecuted a significantly lower number of public officials than any other Eastern European country. ${ }^{89}$ Despite this, Slovak citizens affirmed their low tolerance of corruption in the aftermath of the Jan Kuciak affair, with mass demonstrations that led to the collapse of the government of Robert Fico and the election of a liberal president. Part of the reason for this was resilience to corruption that was built into the Slovak society through the anti-Meciar struggle.

\footnotetext{
${ }^{84}$ Rastislav Kacer and Marian Tupy, 'Out of the Black Hole' Wall Street Journal (New York, 17 February 2005).

${ }^{85}$ Valerie J Bunce, Sharon L Wolchik, Defeating Authoritarian Leaders in Postcommunist Countries (CUP 2011) 53-84.

86 ibid, 77.

${ }^{87}$ Nicolle Gallina, 'Anti-Corruption Revisited: The Case of the Czech Republic and Slovakia' (2013) 7(1) Zeitschrift für Vergleichende Politikwissenschaft 183.

88 Karen Henderson, 'The Slovak Republic: Explaining Defects in Democracy' (2004) 11(5) Democratization 133.

89 Maria Popova and Vincent Post, 'Prosecuting High-Level Corruption in Eastern Europe' (2018) 51(3) Communist and Post-Communist Studies 231.
} 
A full replication of the Slovak strategy wherein pro-European and pro-EU forces were mobilised in one camp with the clear goal of defeating an authoritarian government would not necessarily end corruption and other challenges to the establishment of the rule of law. But there is no doubt that a campaign joining the forces of the EU and civil society, political life, and institutions with such goals would be a promising starting point. The emergence of local actors with a clear anti-corruption agenda, such as the North Macedonian government in 2017 and the short-lived 2019 Canton Sarajevo government in Bosnia and Herzegovina, demonstrates that a lot can be achieved over a short period of time. The EU would clearly support those forces in favour of the rule of law as a tool for ordering societies in a liberal-democratic tradition. ${ }^{90}$

Without such measures, the current rule of law promotion programme of the EU is essentially confined to incremental reforms. Such reforms are not without value, as they change the corruption equilibrium in a society, yet they lack the potential to ignite an anti-corruption campaign and policy reforms that have failed in the WB6 countries while being successful in the Eastern enlargement of 2004. Part of the reason for their success was that the Eastern enlargement represented what in the anti-corruption literature is known as the 'big-bang effect' all-out reform targeting each democratic institution in the country. The effect of these reforms was greatly reinforced by the sense of urgency and optimism about enlargement which prompted a swift en masse adoption and application of the acquis without the numerous action plans that are the norm of the enlargement process today. A change of behaviour among political actors (but also among ordinary citizens who were mobilised through rapid political and legal action) reconfigured the equilibrium of corruption. This is because corruption is self-reinforcing behaviour, which means that high levels of corruption create a 'high corruption trap' that cannot easily be escaped through incremental reforms. ${ }^{92}$ By supporting political alternatives to the existing state capture and by implementing these measures, the EU could help replicate elements of the big-bang enlargement approach.

\footnotetext{
${ }^{90}$ Cf Marovic, Kmezic and Prelec (n 10) 8.

${ }^{91}$ Bo Rothstein, 'Anti-corruption: The Indirect “Big Bang” Approach' (2011) 18(2) Review of International Political Economy 228.

${ }_{92}$ An excellent discussion of the differences between the two approaches is offered in Matthew Stephenson, 'Corruption as a Self-Reinforcing "Trap": Implications for Reform Strategy' (2019) 10 Working Paper Series Quality of Government Institute Gothenburg, <https:// qog.pol.gu.se/digitalAssets/1737/1737653_2019_10_stephenson.pdf> accessed 30 May 2020.
} 


\subsection{Looking beyond law and politics}

As Bugaric has demonstrated, ${ }^{93}$ the rule of law in Central and Eastern Europe has been built simultaneously with democratic institutions and free markets. One of the main axioms of this project was that the rule of law helps economic development by promoting investors' security, stability, and dispute adjudication, thus creating a better business climate. As such, it was heavily promoted by the international financial institutions such as the World Bank. ${ }^{94}$ But could it also be that the rule of law is strengthened by economic development? Some relatively recent empirical findings show a correlation between economic development and the lowering of corruption rates. ${ }^{95}$ This is explained by the success of the private sector in, at least partially, breaking free from the chains of state capture and thus lowering societal dependency on corrupt political machines. Sociological inquiries into the problem of corruption have unearthed a reversal of the maxim that economic growth cannot happen in a corrupt environment. On the contrary, economic growth happens despite the heavy price of systemic corruption..$^{96}$ If we understand corruption as one of the main challenges to the rule of law - as the EU rule of law promotion strategies do - then a reduction in corruption rates could alleviate at least some of the pressures on the establishment of rule of law standards.

This is because the prevalence of corruption in the WB6 is not reinforced only by the existing patrimonial, particularistic, and, essentially, broken system but also by the scarcity of resources. For example, the relatively low payment of health professionals in the WB6 may be an incentive for corrupt behaviour. Experiments and studies have demonstrated that the victims of corruption are often the poor ${ }^{97}$ and that corruption and inequality may create a high corruption equilibrium that is hard to

\footnotetext{
${ }^{93}$ Bojan Bugaric, 'The Rule of Law Derailed: Lessons from the Post-Communist World' (2015) 7 Hague Journal of Rule of Law 175.

${ }^{94}$ Tor Krever, 'The Legal Turn in Late Development Theory: The Rule of Law and the World Bank's Development Model' (2011) 52 Harvard International Law Journal 287.

95 Jie Bai and others, 'Does Economic Growth Reduce Corruption? Theory and Evidence from Vietnam' (2013) National Bureau of Economic Research Working Paper 19483 <www. nber.org/papers/w19483.pdf> accessed 30 May 2020.

${ }^{96}$ Luca Uberti, 'The "Sociological Turn" in Corruption Studies: Why Fighting Graft in the Developing World is Often Unnecessary and Sometimes Counterproductive' (2016) 16(3) Progress in Development Studies 261.

${ }_{97}$ Many studies demonstrate that corrupt exchanges disproportionately target the poor. For example, see Brian Fried, Paul Lagunes and Atheendar Venkataramani, 'Corruption and Inequality at the Crossroad: A Multimethod Study of Bribery and Discrimination in Latin America' (2010) 45(1) Latin American Research Review 76.
} 
break. ${ }^{98}$ Thus, a rise in living standards and economic development could lower incentives for corruption.

Surely, the EU cannot be accountable for the economic development of the non-member states, nor does it have a mandate for structural or fiscal interventions in non-member states. But it is important that it recognises the role that economic development may play in reducing opportunities for corrupt behaviour. To a certain extent, the EU recognised the importance of such a view in its Western Balkans enlargement strategy adopted in 2018. This strategy envisages investment in the development of infrastructure and digital connectivity, as well as the creation of better conditions for the operation of small and medium enterprises. ${ }^{99}$ This translates into more Instrument for Pre-Accession Assistance (IPA) funds and European Bank for Reconstruction and Development (EBRD) loans for these sectors. However, reliance on development funds and loans is not only insufficient as a trigger for the desired transformation, but also creates a risk of strengthening the existing state capture. Namely, the funds coming from these sources end up either in state funds or in public infrastructure projects that present a high risk for corruption. ${ }^{100}$ Another approach, seen in the recent change in the EU accession process methodology, is that, as the rule of law takes centre stage, access to funds for improving various sectors is tied to progress in the rule of law. ${ }^{101}$

Additionally, the EU should consider direct financial intervention in terms of low credit loans into those sectors of the economy that it considers of strategic importance to its development, such as the digital industry and agricultural production. Such loans would help bypass the main obstacle to the efficient functioning of development funds and they would increase independence from the state of small and medium enterprises (SMEs). A cross-cutting approach that intersects with legal

\footnotetext{
${ }_{98}$ Eric Uslaner, 'Corruption, Inequality, and Trust' in Gert Tindgaard Svendsen and Gunnar Lind Haase Svendsen (eds), The Handbook of Social Capital: The Troika of Sociology, Political Science and Economics (Edward Elgar Publishing 2009).

${ }_{99}$ See Commission, 'A credible enlargement perspective for and enhanced EU engagement with the Western Balkans COM(2018) 65 final, 5.

100 This is particularly true in North Macedonia and Bosnia where only $17 \%$ and $18 \%$ of the funds are allocated for support of the private sector. See <https://www.ebrd.com/ ebrd-in-bosnia-and-herzegovina.html> and <https://www.ebrd.com/ebrd-in-north-macedonia.html> for details.

101 'Seven Stages of EU Accession: This is How France Would Reform the Process' (European Western Balkans, 18 November 2019) <https://europeanwesternbalkans. com/2019/11/18/seven-stages-of-eu-accession-this-is-how-france-would-reform-theprocess/> accessed 30 May 2020; Non-Paper Reforming the European Union Accession Process <https://g8fiplkplyr33r3krz5b97dl-wpengine.netdna-ssl.com/wp-content/uploads/2019/11/Enlargement-nonpaper.pdf> accessed 30 May 2020.
} 
mobilisation should complement the usage of these loans. SMEs should be encouraged to comply with procurement laws, report corruption, and adhere to corporate social responsibility standards. This would make legal mobilisation less dependent on CSOs, thereby also helping to relieve them of the stigma of 'foreign agents'. The EU could consider expanding its single market to the WB6 creating, a more integrated relationship with the candidate states, as was done with the European Free Trade Area in the 1990s. ${ }^{102}$ Such a proposal would not necessarily run against the current stream of thinking that strives to tie funds to the fulfilment of the rule of law conditionality criteria. ${ }^{103}$ Rather, it aims to deconstruct the understanding of funding as a 'reward for compliance', seeing it instead as a possible tool that can be used to assist in rule of law promotion.

\section{Conclusion}

Both the states that were outside the EU, such as the WB6, and the states that entered from 2007 onwards transited without transforming. This meant that the creation of liberal democratic institutions and reforms directed towards the creation of a free market were either not fully executed or did not prove themselves to be a panacea for the structural problems existing within society. Different results achieved in the circumstances of the earlier enlargements of 2004, 2007 and 2013 emphasise that not all of the current failures in rule of law promotion may be explained by the lack of adoption and implementation of rule of law standards but that they are also a consequence of the pervasive state capture that the promotion fails to tackle.

This has led to the paradox of the increased robustness of rule of law conditionality that is not followed by an adequate strengthening of the rule of law. Despite the relatively longer period that the WB6 states and the EU have had to work out a more functional approach, this has not resulted in the overcoming of phenomena such as fake compliance with EU rule of law standards.

Regardless of the EU's future intentions concerning enlargement or quasi-membership status, rule of law promotion in the WB6 is not meaningless. On the contrary, the activities may prevent further democratic backsliding, making the countries in question a more reliable partner to the EU in different fields of cooperation. Given the relatively long timespan over which they are evolving and the lack of leverage, such as membership, it can be said that what it has achieved so far is not to be

${ }^{102}$ European Stability Initiative (n 10) 14, 22.

${ }^{103}$ For example, see Nozar (n 16) 3. 
downplayed. Certainly, the EU and its Member States will in the course of the enlargement process ultimately have to decide whether or not they consider that the WB6 states possess the required rule of law standards. An answer to this question, irrespective of whether it is affirmative or negative, will have little sense without an attempt to promote the rule of law through strengthening rule of law constituency. Without such a development, WB6 rulers will have an incentive to turn into unenlightened despots who will seek partnership in exchange for assistance in conflict prevention. And the citizens themselves will seek refuge in the prospering EU countries rather than risk standing up to injustice. The mere reiteration of the importance of legalism built into the expansion of good governance conditionality will not challenge the paradigm of 'stabilitocracy'.

In this paper, I have mapped the main general elements missing in the rule of law promotion approach, arguing why they would be useful in confronting state capture. None of the approaches presented are completely new or revolutionary and all of them have weaknesses and limitations. What their application demands is not so much funds from European taxpayers, but a reframing of the past experiences of enlargement and rule of law promotion, as well as recognition that many of the successes depended on a variety of factors. This does not mean that the bar for the evaluation of rule of law standards should be set lower, but that a wider approach which takes into account the many dimensions of promotion should allow for a refocusing of the promotion project.

\section{(c) $(1)(9)$}

This work is licensed under the Creative Commons Attribution - Non-Commercial - No Derivatives 4.0 International License.

Suggested citation: N Hogić, 'The European Union's Rule of Law Promotion in the Western Balkans: Building a Rule of Law Constituency' (2020) 16 CYELP 197. 